\title{
LATEX SENSITIZATION AND RISK FACTORS IN FEMALE NURSES IN THAI GOVERNMENTAL HOSPITALS
}

\section{CHOMPUNUCH SUPAPVANICH ${ }^{1,2}$, ANDREW C. POVEY ${ }^{2}$, and FRANK DE VOCHT ${ }^{2}$}

${ }^{1}$ Sirindhorn College of Public Health, Yala, Thailand

Department of Public Health

${ }^{2}$ The University of Manchester, Manchester, United Kingdom

Centre for Occupational and Environmental Health, Centre for Epidemiology, Institute of Population Health, Manchester Academic Health Science Centre

\begin{abstract}
Objectives: Exposure to latex allergens in latex gloves can cause occupational health problems in nurses, yet latex gloves are still widely used in Thai hospitals. Therefore, we conducted a study to determine the prevalence of latex sensitization in nurses and identify risk factors associated with sensitization. Materials and Methods: A questionnaire, providing information on personal characteristics, ill-health, working conditions and symptoms related to latex product use, was administered to 363 female nurses working in two tertiary hospitals in southern Thailand. Latex sensitization was confirmed using a solid phase immunoassay to detect anti-latex IgE antibodies. Total glove protein levels were determined by using a modified Lowry method and latex aeroallergens by a competitive inhibition immunoassay. Results: The overall prevalence of latex sensitization was $4.4 \%$. Respiratory symptoms related to latex glove use were significantly associated with latex sensitization $\left(\mathrm{OR}=5.5,95 \%\right.$ CI: 1.57-19). Total glove protein levels ranged 87.8-250.8 $\mu \mathrm{g}$ protein $/ \mathrm{dm}^{2}$. The prevalence of latex sensitization was higher $(6.6 \%$ vs. $2.2 \%)$ in the hospital where gloves with higher protein levels ( $82-438 \mu \mathrm{g} / \mathrm{g}$ vs. $86-170 \mu \mathrm{g} / \mathrm{g})$ were used. Furthermore, latex sensitization prevalence increased from 3\% to 5\% with increased average departmental aeroallergen concentrations. Conclusions: Latex sensitization prevalence in Thai nurses was higher than previously reported. Respiratory exposure seems to play an important role, in addition to dermal exposure. If latex gloves cannot be replaced by non-latex alternatives, replacement with gloves with lower protein content should be considered.
\end{abstract}

Key words:

Sensitization, Nursing, Latex allergy, Developing world, Occupational asthma, Occupational dermatitis

\section{INTRODUCTION}

Exposure to latex allergens can cause occupational health problems in health care workers (HCWs) particularly, but not limited to, those who use latex gloves [1]. Clinical manifestations related to latex glove use can present themselves as relatively minor symptoms such as skin irritation, contact dermatitis, eye irritation and rhinitis, but can also manifest as serious symptoms, including asthma and anaphylaxis [2,3]. The prevalence of latex allergy in HCWs has been reported to range from $2-17 \%$, with data from Thailand indicating a relatively low prevalence of about $2 \%$ in Thai nurses wearing latex gloves at work [4]. Non-occupational factors such as atopic diseases [5], allergy to certain foods [6] and having had multiple

This work was supported by a $\mathrm{PhD}$ grant from The Royal Thai Government.

Corresponding author: F. de Vocht, Centre for Occupational and Environmental Health, The University of Manchester, Oxford Road, Manchester, UK, M13 9PL (e-mail: frank.devocht@manchester.ac.uk). 
operations [7] have also been shown to be risk factors for the development of latex allergy. The main occupational risk factor however, especially in HCWs, is the frequent use of powdered latex gloves (PLGs) [9], although other latex products are also used in healthcare settings [8]. Over the previous decades, the prevalence of latex allergy has decreased in many countries, particularly western societies, due to the use of alternative gloves [10-13]. In contrast, PLGs are still frequently used in developing countries such as Thailand as the price of PLGs is lower than for other types of gloves [14].

Relatively little research has been conducted on the prevalence and incidence of latex allergy in the healthcare sector in Thailand. The limited data that are available suggest both a frequent use of PLGs but also a relatively low prevalence of latex sensitization. The absence of populationspecific data on adverse symptoms related to latex glove use and on occupational risk factors do not enable further speculation about the apparent deviation of these data from that reported elsewhere. Therefore, the aims of this study were to (i) determine the prevalence of latex sensitization in the nursing population in government hospitals in Thailand and compare these with western societies, and (ii) characterize occupational risk factors and determine health effects related to glove use by nurses. The latter was specifically of interest since this may enable targeted interventions that would not necessarily require substitution to alternative (more expensive) non-latex powdered gloves.

\section{MATERIALS AND METHODS}

This cross-sectional study was conducted among nurses working in one of the two tertiary hospitals in the south of Thailand. Study information sheets, consent forms and a self-administered questionnaire were sent to the head of the nursing groups who then distributed them to all nurses who worked in the following locations (outpatient departments, emergency room, operating theatres, medical and surgical wards, labour and delivery units, ophthalmic wards, obstetric wards, paediatric wards, eye, nose and throat wards). The questionnaire included questions on demographics, working conditions, use of latex gloves and other latex products in the workplace and about other known or suspected risk factors for the development of latex allergy. In addition the questionnaire included questions on the prevalence of illnesses and symptoms related to the use of latex gloves.

All participating nurses were further invited to donate a blood sample. Blood samples were collected, centrifuged, and serum was collected and frozen at $-20^{\circ} \mathrm{C}$ until analysed. Specific IgE latex-antibody levels were measured in the serum samples using a solid-phase, enzyme-labelled fluoroenzyme-immunoassay (latex UniCAP Specific IgE Assay) on a UniCAP 100 automated analyzer (Pharmacia Diagnostic AB, Uppsala, Sweden). The limit of detection of the assay was $0.35 \mathrm{kU}_{\mathrm{A}} / 1$. The sensitivity and specificity of this solid-phase assay has been reported to be $90 \%$ and $98.3 \%$, respectively [15].

Total water soluble protein content was quantified for the three main types of latex gloves used in each of the hospitals (i.e. powdered examination, powdered surgical and re-usable sterile gloves) using a modified Lowry method [16]. Briefly, water-soluble proteins were extracted using an aqueous phosphate buffer of $\mathrm{pH}=7.4$ and proteins were precipitated using sodium hydroxide. Proteins were re-dissolved in alkaline copper tartrate solution and quantified colorimetrically at $750 \mathrm{~nm}$. Concentrations of protein in the PLGs are reported as microgram per gram $(\mu \mathrm{g} / \mathrm{g})$ of latex glove. The sensitivity was $50 \mu \mathrm{g} / \mathrm{g}$ [17]. Latex aeroallergens were detected by using a Pharmacia CAP competitive inhibition immunoassay [18]. The Pharmacia CAP system is a solid-phase enzyme immunoassay using non-ammoniated NRL allergens ( $\mathrm{k} 82$, a crude protein extract from latex spiked with recombinant Hev b 5). Briefly, inhalable dust was measured using stationary sampling at $2 \mathrm{l} / \mathrm{min}$ for eight hours in the 
departments where participating nurses worked. Natural rubber latex (NRL) allergens in each PTFE filter membrane were extracted in $2 \mathrm{ml}$ of phosphate buffered saline ( $\mathrm{PBS}=0.15 \mathrm{M}, \mathrm{pH}=7.2$ ) overnight at room temperature $\left(25^{\circ} \mathrm{C}\right)$. In the inhibition immunoassay, $0.2 \mathrm{ml}$ of latex allergen or glove protein (reference) extracts were incubated with $0.2 \mathrm{ml}$ pooled sera of 10 latex sensitised nurses (i.e. positive for anti-latex IgE antibodies) for $2 \mathrm{~h}$ at $25^{\circ} \mathrm{C}$. Protein extracts from powdered latex examination gloves available from each hospital (total protein $0.49 \mathrm{mg} / \mathrm{ml}$ for hospital 1 and $0.17 \mathrm{mg} / \mathrm{ml}$ for hospital 2) were used as the reference material for the analysis of NRL allergen concentrations on PTFE filters. The reading was transformed to ng per ml using a standard curve. Results of NRL aeroallergen levels were transformed into nanogram per cubic meter $\left(\mathrm{ng} / \mathrm{m}^{3}\right)$.

\section{Ethics}

The study was approved by the Ethical Committee of the University of Manchester (ref 08117) and both participating hospitals (ref. YL0027.102/17050 and ref. ST0516.10/7174, respectively).

\section{Statistics}

Data were analysed using T-tests or Mann-Whitney U tests for continuous data depending on the distributions, while categorical data were assessed by $\mathrm{Chi}^{2}$ tests or by Fisher's exact test for small numbers $(\mathrm{N}<5)$. Associations between potential risk factors and latex allergy were determined using univariate and multiple logistic regression. Multiple regression models were obtained by backwards selection using a 5\% statistical significance level as the cut-off. Odds ratios (OR) and 95\% confidence intervals $(95 \% \mathrm{CI}$ ) are presented to describe associations between risk factors and NRL glove related symptoms and NRL sensitization. All analyses were done using SPSS (IBM, UK) version 19.

\section{RESULTS}

Of a total of 665 nurses, 363 (55.9\%) agreed to participate in the study and returned the consent form, the self-reported questionnaire and provided a blood sample. The age of nurses ranged from 23 to 60 years (mean $\pm \mathrm{SD}=36.8$ years \pm 8.4 ) with the nursing population in hospital 2 on average 3 years older than those in hospital 1 (Table 1).

Table 1. Demographics of participating nurses in serological testing stratified by hospital

\begin{tabular}{|c|c|c|c|c|}
\hline \multirow[b]{2}{*}{ Variables } & \multicolumn{3}{|c|}{ Nurses } & \multirow[b]{2}{*}{$\mathrm{p}^{\mathrm{a}}$} \\
\hline & $\begin{array}{c}\text { total } \\
(\mathrm{N}=363)\end{array}$ & $\begin{array}{c}\text { in hospital } 1 \\
(\mathrm{~N}=183)\end{array}$ & $\begin{array}{c}\text { in hospital } 2 \\
(\mathrm{~N}=180)\end{array}$ & \\
\hline Age (years) & & & & $<0.01^{\mathrm{b}}$ \\
\hline $\mathrm{M} \pm \mathrm{SD}$ & $36.8 \pm 8.4$ & $35.3 \pm 7.9$ & $38.4 \pm 8.7$ & \\
\hline $\mathrm{Me}$ & 35.0 & 34.0 & 37.0 & \\
\hline $\min .-\max$ & $23.0-60.0$ & $23.0-57.0$ & $23.0-60.0$ & \\
\hline Ethnicity, n (\%) & & & & $<0.01$ \\
\hline Thai & $287(79.1)$ & $163(89.1)$ & $130(67.7)$ & \\
\hline Thai-Chinese & $16(4.4)$ & $6(3.3)$ & $10(5.2)$ & \\
\hline Thai-Malaysian & $60(16.5)$ & $14(7.7)$ & $52(27.1)$ & \\
\hline Education, n (\%) & & & & 0.19 \\
\hline diploma & $20(5.3)$ & $5(2.7)$ & $15(7.8)$ & \\
\hline bachelor & $321(85.6)$ & $158(86.3)$ & $163(84.9)$ & \\
\hline master & $34(9.1)$ & $20(10.9)$ & $14(7.3)$ & \\
\hline
\end{tabular}


Table 1. Demographics of participating nurses in serological testing stratified by hospital - cont.

\begin{tabular}{|c|c|c|c|c|}
\hline \multirow[b]{2}{*}{ Variables } & \multicolumn{3}{|c|}{ Nurses } & \multirow[b]{2}{*}{$\mathrm{p}^{\mathrm{a}}$} \\
\hline & $\begin{array}{c}\text { total } \\
(\mathrm{N}=363)\end{array}$ & $\begin{array}{l}\text { in hospital } 1 \\
(\mathrm{~N}=183)\end{array}$ & $\begin{array}{c}\text { in hospital } 2 \\
(\mathrm{~N}=180)\end{array}$ & \\
\hline Position, $\mathrm{n}(\%)$ & & & & $<0.01$ \\
\hline registered nurses & $346(95.3)$ & $180(98.4)$ & $166(92.2)$ & \\
\hline technical/practical nurses & $17(4.7)$ & $3(1.6)$ & $14(7.8)$ & \\
\hline Work period, $\mathrm{n}(\%)$ & & & & 0.02 \\
\hline$<10$ years & $114(1.4)$ & $70(38.3)$ & $44(24.4)$ & \\
\hline $10-20$ years & $147(40.5)$ & $65(35.5)$ & $82(45.6)$ & \\
\hline$>20$ years & $102(28.1)$ & $48(26.2)$ & $54(30.0)$ & \\
\hline Work shift, n (\%) & & & & $<0.01$ \\
\hline$\leq 35 \mathrm{~h} /$ week & $143(39.5)$ & $57(31.3)$ & $86(47.8)$ & \\
\hline$>35 \mathrm{~h} /$ week & $219(60.5)$ & $125(68.7)$ & $94(52.2)$ & \\
\hline
\end{tabular}

M - mean; Me - median; SD - standard deviation.

${ }^{\text {a }} \mathrm{P}$-value by $\mathrm{Chi}^{2}$ test.

${ }^{\text {b }}$ P-value by Mann-Whitney U test.

Approximately $79 \%$ of all participating nurses were Thai, with $17 \%$ and $4 \%$ being Thai-Malaysian and Thai-Chinese nurses, respectively. Hospital 2 had more Thai-Malaysian nurses employed than hospital 1 , and also had a higher percentage (8\% vs. $2 \%$ ) of technical/practical nurses. Participating nurses in hospital 2 had been employed for slightly longer than those in hospital 1, while nurses in hospital 1 more often worked longer than 35 hours per week (69\%) compared to those in hospital $2(52 \%)$. Sixteen nurses were positive for anti-NRL IgE antibodies, indicating an overall latex sensitization prevalence of $4.4 \%$. However, the prevalence in hospital 1 was three times greater $(6.6 \%)$ than that in hospital $2(2.2 \%)$ and reached borderline statistical significance ( $p=0.07$; Table 2). Stratification by ward indicated that the highest prevalence of sensitized nurses (13\%) was found in the labour wards (3 out of 24 participants). None of the nurses in the outpatient departments $(\mathrm{N}=33)$ and emergency units $(\mathrm{N}=21)$ were positive for anti-NRL IgE antibodies.

Of the 16 sensitized nurses, $8(50 \%)$ reported health symptoms related to their use of latex gloves, which was significantly higher than that reported by the non-sensitized nurses (18\%). More specifically, statistically significant 4-fold and 6-fold increased risks for sensitization were observed for nurses who reported experiencing dermal effects and respiratory effects self-attributed to the use of NRL, respectively (Table 3). Of the 8 nurses who reported health effects, 4 reported dermal symptoms only, 2 reported respiratory symptoms only and 2 reported both. Dermal problems were eczema $(\mathrm{N}=6)$ and face and lip swelling $(\mathrm{N}=1)$, respiratory symptoms were rhinitis $(\mathrm{N}=1)$ and sneezing $(\mathrm{N}=3)$, while furthermore one nurse also reported eye irritation $(\mathrm{N}=1)$. Other known risk factors, including allergy, atopy or asthma, familial atopy, or multiple operations showed no significantly increased risk for sensitization in this population.

Risk of latex sensitization was not significantly associated with specific occupational determinants although, on average, sensitized nurses seemed to have been less exposed than non-sensitized nurses in that they had worked about two years less than non-sensitized nurses, reported 
Table 2. Prevalence of anti-latex $\operatorname{IgE}$ antibodies amongst female nurses

\begin{tabular}{|c|c|c|c|c|}
\hline \multirow{2}{*}{ Study area } & \multirow{2}{*}{$\begin{array}{l}\text { Nurses } \\
\text { (n) }\end{array}$} & \multicolumn{2}{|c|}{$\begin{array}{c}\text { Anti-latex IgE antibodies } \\
\mathrm{n}(\%)\end{array}$} & \multirow{2}{*}{$\mathrm{p}^{\mathrm{a}}$} \\
\hline & & $\begin{array}{c}\text { normal } \\
\left(<0.35 \mathrm{Ku}_{\mathrm{A}} l\right)\end{array}$ & $\begin{array}{c}\text { positive } \\
\left(\geq 0.35 \mathrm{Ku}_{\mathrm{A}} / \mathrm{l}\right)\end{array}$ & \\
\hline Total & 363 & $347(95.6)$ & $16(4.4)$ & \\
\hline hospital 1 & 183 & $171(93.4)$ & $12(6.6)$ & 0.07 \\
\hline hospital 2 & 180 & $176(97.8)$ & $4(2.2)$ & \\
\hline \multicolumn{5}{|l|}{ Workplaces } \\
\hline outpatient departments & 33 & $33(100.0)$ & - & 0.12 \\
\hline emergency units & 21 & $21(100.0)$ & - & \\
\hline intensive care units & 63 & $62(98.4)$ & $1(1.6)$ & \\
\hline medical wards & 54 & $52(96.3)$ & $2(3.7)$ & \\
\hline surgical wards & 81 & $77(95.1)$ & $4(4.9)$ & \\
\hline labour units & 24 & $21(87.5)$ & $3(12.5)$ & \\
\hline obstetrics wards & 36 & $32(88.9)$ & $4(11.1)$ & \\
\hline operating theatres & 51 & $49(96.1)$ & $2(3.9)$ & \\
\hline
\end{tabular}

a P-value by Chi ${ }^{2}$ test.

Table 3. Associations between non-occupational and occupational factors and natural rubber latex (NRL) sensitization in female nurses

\begin{tabular}{|c|c|c|c|}
\hline Variable & $\begin{array}{c}\text { Sensitized } \\
\mathrm{n}(\%)\end{array}$ & $\begin{array}{c}\text { Non-sensitized } \\
\mathrm{n}(\%)\end{array}$ & $\begin{array}{c}\mathrm{OR}^{\mathrm{a}} \\
(95 \% \mathrm{CI})\end{array}$ \\
\hline \multicolumn{4}{|l|}{ History of operation } \\
\hline no operations & $8(50.0)$ & $161(46.7)$ & 1.00 \\
\hline single operation & $3(18.8)$ & $98(28.4)$ & $0.6(0.2-2.4)$ \\
\hline multiple operations & $5(31.3)$ & $86(24.9)$ & $1.2(0.4-3.7)$ \\
\hline \multicolumn{4}{|l|}{ Familial atopy } \\
\hline no & $10(62.5)$ & $222(64.2)$ & 1.00 \\
\hline yes & $6(37.5)$ & $124(35.8)$ & $1.1(0.4-3.0)$ \\
\hline \multicolumn{4}{|l|}{ Types of personal illness } \\
\hline no symptoms & $11(68.8)$ & $209(60.4)$ & 1.00 \\
\hline dermal symptoms & $3(18.8)$ & $115(33.1)$ & $0.3(0.1-1.8)$ \\
\hline eczema & $1(6.3)$ & $59(17.1)$ & $0.3(0.0-2.5)$ \\
\hline urticaria & $3(18.8)$ & $94(27.2)$ & $0.6(0.2-2.2)$ \\
\hline \multicolumn{4}{|l|}{ Other symptoms } \\
\hline asthma & $2(12.5)$ & $15(4.3)$ & $3.2(0.7-15.1)$ \\
\hline atopy & $3(18.8)$ & $89(25.7)$ & $0.7(0.2-2.4)$ \\
\hline grass allergy & $2(12.5)$ & $30(8.7)$ & $1.5(0.3-6.9)$ \\
\hline hay fever & $2(12.5)$ & $35(10.1)$ & $1.3(0.3-5.8)$ \\
\hline
\end{tabular}


Table 3. Associations between non-occupational and occupational factors and natural rubber latex (NRL) sensitization in female nurses - cont.

\begin{tabular}{|c|c|c|c|}
\hline Variable & $\begin{array}{l}\text { Sensitized } \\
\mathrm{n}(\%)\end{array}$ & $\begin{array}{c}\text { Non-sensitized } \\
\mathrm{n}(\%)\end{array}$ & $\begin{array}{c}\mathrm{OR}^{\mathrm{a}} \\
(95 \% \mathrm{CI})\end{array}$ \\
\hline \multicolumn{4}{|l|}{ Food allergy } \\
\hline no & $14(87.5)$ & $299(87.4)$ & 1.00 \\
\hline yes & $2(12.5)$ & $43(12.6)$ & $1.0(0.2-4.5)$ \\
\hline \multicolumn{4}{|c|}{ Dermal symptoms related to NRL gloves } \\
\hline no & $10(62.5)$ & $299(86.2)$ & 1.00 \\
\hline yes & $6(37.5)$ & $48(13.8)$ & $3.7(1.3-10.8)$ \\
\hline \multicolumn{4}{|c|}{ Respiratory symptoms related to NRL gloves } \\
\hline no & $12(75.0)$ & $327(94.2)$ & 1.00 \\
\hline yes & $4(25.0)$ & $20(5.8)$ & $5.5(1.6-18.4)^{\mathrm{b}}$ \\
\hline \multicolumn{4}{|c|}{ Other symptoms ${ }^{c}$ related to NRL glove use } \\
\hline no & $15(93.8)$ & $341(98.3)$ & 1.00 \\
\hline yes & $1(6.3)$ & $6(1.7)$ & $3.8(0.4-33.5)$ \\
\hline \multicolumn{4}{|l|}{ Work shift } \\
\hline$\leq 35 \mathrm{~h} /$ week & $5(31.3)$ & $138(39.9)$ & 1.00 \\
\hline$>35 \mathrm{~h} /$ week & $11(68.8)$ & $208(60.1)$ & $1.5(0.5-4.3)$ \\
\hline \multicolumn{4}{|l|}{ Frequency of hand washing } \\
\hline 1-10 times/day & $3(18.8)$ & $104(30.3)$ & 1.00 \\
\hline 11-20 times/day & $9(56.3)$ & $126(36.7)$ & $2.5(0.7-9.4)$ \\
\hline$>20$ times/day & $4(25.0)$ & $113(32.9)$ & $1.2(0.3-5.6)$ \\
\hline p-trend & & & 0.86 \\
\hline \multicolumn{4}{|c|}{ Types of hand detergent (vs. non-users) } \\
\hline alcohol hand rub & $13(81.3)$ & $252(72.6)$ & $1.6(0.5-5.9)$ \\
\hline chlorhexidine & $9(56.3)$ & $232(66.9)$ & $0.6(0.3-1.8)$ \\
\hline povidone scrub & $1(6.3)$ & $50(14.4)$ & $0.4(0.1-3.1)$ \\
\hline soap & $8(50.0)$ & $132(38.0)$ & $1.6(0.6-4.4)$ \\
\hline \multicolumn{4}{|l|}{ PLG use } \\
\hline$\leq 5$ pairs $/$ day & $5(31.3)$ & $79(24.1)$ & 1.00 \\
\hline 6-15 pairs/day & $7(43.8)$ & $135(41.2)$ & $0.8(0.3-2.7)$ \\
\hline$>15$ pairs/day & $4(25.0)$ & $101(30.8)$ & $0.6(0.2-2.4)$ \\
\hline p-trend & & & 0.79 \\
\hline \multicolumn{4}{|l|}{ Time spent wearing PLG } \\
\hline$\leq 2 \mathrm{~h} /$ day & $7(43.8)$ & $126(38.8)$ & 1.00 \\
\hline $3-5$ h/day & $4(25.0)$ & $103(31.7)$ & $0.7(0.2-2.5)$ \\
\hline 6-8 h/day & $5(31.3)$ & $83(25.5)$ & $1.1(0.3-3.5)$ \\
\hline p-trend & & & 0.95 \\
\hline
\end{tabular}

OR - odds ratio; $\mathrm{CI}$ - confidence interval.

a Unadjusted.

${ }^{\mathrm{b}}$ Only variable significant after adjustment for age, with OR $=5.47$ (95\% CI: 1.57-19).

${ }^{c}$ Other symptoms included eye irritation and/or face and lip swelling. 
a shorter duration of latex glove-usage, used fewer pairs of powdered latex gloves per day and wore them less during the day as well (Table 3). None of the specific potential occupational risk factors, including a high frequency of hand washing, long work shifts, a high frequency of hand washing, the use of specific hand detergents, the number of powdered latex gloves used per day and the time spent wearing gloves per day, were associated with increased sensitization risk.

After adjustment for age, self-reported respiratory symptoms self-attributed to latex glove use was the most important predictor, indicating a 5-6 fold increased risk (95\% CI: 1.6-19.0) (Table 3).

The water-soluble total protein concentrations of the three main types of gloves (examination, surgical and reusable sterile gloves) used in both hospitals are shown in Table 4. Protein concentration in powdered examination gloves used in hospital 1 was 2-3 times higher than in those used in hospital 2 (438 $\mu \mathrm{g} / \mathrm{g}$ vs. $170 \mu \mathrm{g} / \mathrm{g})$, and for surgical gloves nearly twice as high $(198 \mu \mathrm{g} / \mathrm{g}$ vs. $109 \mu \mathrm{g} / \mathrm{g})$. The concentrations in the re-usable sterile gloves were similar in both hospitals. Interestingly, the magnitude of these observed differences in water-soluble total protein concentrations on the main types of gloves used was of the same order of magnitude as the differences in latex sensitization rates between hospital $1(6.6 \%)$ and hospital $2(2.2 \%)$.

Furthermore, a trend of increased prevalence of NRL sensitization with increased NRL aero-allergen concentrations in departments where the nurses worked could be observed (Table 5). Measured aeroallergen concentrations were stratified into low $\left(<6.5 \mathrm{ng} / \mathrm{m}^{3}\right)$, moderate $\left(6.6-7 \mathrm{ng} / \mathrm{m}^{3}\right)$ and high $\left(7-9.4 \mathrm{ng} / \mathrm{m}^{3}\right)$ concentration groups and the corresponding sensitization prevalences were $3 \%, 3.3 \%$ and $4.8 \%$, respectively. Three- to four-fold and 6-8 fold increased ORs were observed for the moderate and high exposed nurses, but these differences did not reach statistical significance.

Table 4. Water-soluble protein levels in powdered latex glove (PLG) extracts

\begin{tabular}{|c|c|c|c|}
\hline \multirow[t]{2}{*}{$\mathrm{PLG}^{\mathrm{a}}$} & \multicolumn{2}{|c|}{$\begin{array}{c}\text { Total proteins } \mathrm{s}^{\mathrm{a}, \mathrm{b}} \\
\text { ( } \mu \mathrm{g} \text { protein/g of rubber glove) } \\
\mathrm{M} \pm \mathrm{SD}\end{array}$} & \multirow[t]{2}{*}{$\mathrm{p}^{\mathrm{c}}$} \\
\hline & hospital 1 & hospital 2 & \\
\hline Examination gloves & $438.1 \pm 24.6$ & $169.8 \pm 4.9$ & $<0.01$ \\
\hline Surgical gloves & $197.9 \pm 9.8$ & $109.4 \pm 7.9$ & $<0.01$ \\
\hline Reusable sterile gloves & $82.0 \pm 5.0$ & $86.4 \pm 4.0$ & 0.30 \\
\hline
\end{tabular}

${ }^{\text {a }}$ Each type of glove was from the same lot or box.

${ }^{\mathrm{b}}$ Total NRL proteins was measured using modified Lowry method.

${ }^{c} \mathrm{P}$-value by independent T-test.

Table 5. Associations between average NRL aeroallergen and NRL sensitisation

\begin{tabular}{lcccc}
\hline \multicolumn{1}{c}{ Exposure } & $\begin{array}{c}\text { Sensitised } \\
\mathrm{n}(\%)\end{array}$ & Non-sensitised $\mathrm{n}(\%)$ & $\mathrm{OR}_{\text {unadj }}$ & OR $_{\text {adj }}{ }^{\text {a }}$ \\
\hline $\begin{array}{l}\text { NRL aeroallergen } \\
\text { low }^{\mathrm{b}}\end{array}$ & $3(3.0)$ & $96(97.0)$ & & \\
moderate $^{\mathrm{c}}$ & $4(3.3)$ & $119(96.7)$ & $3.3(0.4-30.4)$ & 3.00 \\
\hline
\end{tabular}


Table 5. Associations between average NRL aeroallergen and NRL sensitisation - cont.

\begin{tabular}{lcccc}
\hline \multicolumn{1}{c}{ Exposure } & $\begin{array}{c}\text { Sensitised } \\
\mathrm{n}(\%)\end{array}$ & Non-sensitised n $(\%)$ & $\mathrm{OR}_{\text {unadj }}$ & OR $_{\text {adj }}{ }^{a}$ \\
\hline high $^{\mathrm{d}}$ & $5(4.8)$ & $99(95.2)$ & $7.9(1.0-65.0)$ & $6.8(0.7-68.4)$ \\
p-trend & & & 0.03 & 0.08 \\
\hline
\end{tabular}

a Adjustment for age, hospital, ethnicity and atopy.

${ }^{\mathrm{b}}<6.5 \mathrm{ng} / \mathrm{m}^{3}$.

${ }^{c} 6.6-7 \mathrm{ng} / \mathrm{m}^{3}$.

d $7.0-9.4 \mathrm{ng} / \mathrm{m}^{3}$.

Other abbreviations as in Table 3 .

\section{DISCUSSION}

The prevalence of anti-latex $\mathrm{IgE}$ antibodies among female nurses in this study was $4.4 \%$, and more specifically was $2.2 \%$ and $6.6 \%$ in the individual hospitals. These rates are higher than the largest and most recent published study (2006) in Thai nurses which reported a prevalence of $2 \%$ [4]. A higher prevalence has been reported in other Asian countries: in Singapore (2005) 32 of 381 HCWs (8.4\%) were positive for anti-latex IgE antibodies using skin prick testing [19], in Indonesia a latex sensitization rate of $6.1 \%$ amongst nurses was reported based on skin prick testing and in Taiwan (2008) 152 of 1139 HCWs (12\%) had positive latex skin prick tests [20].

In a second study in Taiwan however, which used Pharmacia CAP radioallergosorbent testing, a lower prevalence $(2.3 \%)$ was reported amongst 130 nurses [21]. The relatively low latex sensitization prevalence in this study when compared to levels observed in hospitals from other Asian countries (but not to Thailand itself) may be due to the differences in working conditions, types of PLG use, duration of time wearing latex gloves and personal characteristics. However, it is difficult, if not impossible, to directly compare latex allergy prevalence rates amongst different populations as different methods have been used [9].

Stratification by ward indicated that the prevalence of latex sensitization was highest (12.5\%: 3 of 24 nurses) in the labour units, followed by $11.1 \%$ (4/36) in the obstetric wards, $4.9 \%(4 / 81)$ in the surgical wards, $3.9 \%(2 / 51)$ in the operating theatres, $3.7 \%$ (2/54) in the medical wards and $1.6 \%(1 / 63)$ in the intensive care units. Occupational situations with a similar high prevalence were also found in a study of Bangkok dental students for which a prevalence of $14 \%$ was reported [22]. In other Asian countries, a study in Korea (2002) reported, based on skin prick testing, that 9 of 80 operating nurses $(11.3 \%$ ) were positive to latex glove extract [23].

This current study found no specific occupational risk factors that were associated with latex sensitization. This is not consistent with previous findings in the region indicating strong associations between latex sensitization and especially the use of (powdered) latex gloves [9,20,24]. Most likely this can be explained by the small number of latex sensitized nurses $(\mathrm{N}=16)$, while also the (historical) use of gloves was determined by self-reporting, which is likely to have been associated with a large degree of misclassification [4,25]. Additionally, this study had a cross-sectional design that is susceptible to interpretation problems because exposure and disease are measured at the same point in time. It is also possible that nurses suffering from allergic symptoms may have left their jobs or have been transferred to other wards or administrative functions (healthy worker effect) [13]. Indeed, on average, sensitized nurses had worked about two years less than non-sensitized nurses, and reported using less pairs of powdered latex gloves per day, wearing 
them for shorter periods during the day and overall having used them less.

The participation rate in this study was $56 \%$ and because participation was voluntary this may have resulted in selection bias. Data were available that enabled comparison between participating and non-participating nurses and these indicated that whereas both groups had a similar age distribution, there were minor differences between both groups in that participating nurses had a higher percentage of native Thai nurses compared to non-participants (79\% vs. $73 \%$, respectively) and more often reported having a non-work related allergic disease (39\% vs. 29\%, respectively). It is however unknown if these correlate to latex-specific sensitization and if this biased the sample.

Although it has been shown that methods to determine latex allergy, including the one used in this study based on latex-specific IgE levels using Pharmacia UniCAP (Uppsala, Sweden), do not necessary correlate well with reported symptoms of type I allergy [26], our results indicate that the best predictive factor of latex sensitization was respiratory symptoms, and not dermal symptoms, that were self-attributed to glove use. This may indicate, together with the absence of glove-use as a risk factor, that inhalation may also be an important route of developing latex sensitization in this study population. This suggests that the nurses were likely to experience relatively high aero-allergen exposure [27]. Indeed, the result of the current study also indicated that latex sensitisation tended to increase with increasing latex aeroallergen exposure.

Interestingly, the amount of glove proteins may have an influence on the prevalence of latex sensitization, as results indicated that the hospital with the higher prevalence of anti-latex IgE antibodies also used PLGs with higher total protein levels. Although this is an association at an ecological level, this may imply that if switching to nonpowdered alternatives is not financially feasible, then switching to gloves with lower proteins may well reduce the incidence of new allergy in these populations; an intervention measure that has already been demonstrated to be effective over a decade ago [28].

In conclusion, the prevalence of latex sensitization in nurses in governmental hospitals in Thailand in this study was $4.4 \%$ (range: $2.2-6.6 \%$ ), which was 2-3 times higher than previously reported. Latex sensitization was associated with the presence of respiratory symptoms self-attributed to latex glove use, and at an ecological level the protein content of the gloves used in the hospitals was associated with the prevalence of sensitization. No other specific risk factors were identified in this study, but these data do indicate that the inhalation route of exposure, in addition to the dermal route, may also have an important role to play.

\section{ACKNOWLEDGEMENTS}

This work was supported by The Royal Thai Government. The researchers would like to thank directors and heads of nurses for their help to collect data in hospitals. Moreover, we would like to thank all participating nurses and staff from the centre for occupational health and laboratory technicians for their help and support in this study.

\section{REFERENCES}

1. Cremer R, Lorbacher M, Hering F, Engelskirchen R. Natural rubber latex sensitisation and allergy in patients with spina bifida, urogenital disorders and oesophageal atresia compared with a normal paediatric population. Eur J Pediatr Surg. 2007;17(3):194-8, http://dx.doi. org/10.1055/s-2007-965144.

2. Inal MT, Memis D, Top H, Bahar M, Celik ESEY, Kement B. Latex-onset pulmonary edema and disseminated intravascular coagulation due to latex anaphylaxis. Anesthetic Plast Surg. 2010;34:394-6, http://dx.doi.org/10.1007/s00266-009-9412-2. 3. Green-Mckenzie J, Hudes D. Grand rounds: latex-induced occupational asthma in a surgical pathologist. Environ Health Persp. 2005;113:888-93, http://dx.doi.org/ 10.1289/ehp.7830. 
4. Chaiear N, Jindawong B, Boonsawas W, Kanchanarach T, Sakunkoo P. Glove allergy and sensitization to natural rubber latex among nursing staff at Srinagarind hospital, Khon Kaen, Thailand. J Med Assoc Thai. 2006;89:368-76.

5. Suli CL, Praziale M, Lorini M, Silva ED, Miadonna A, Tedeschi A. Prevalence and risk factors for latex allergy: A cross sectional study on health-care workers of an Italian hospital. J Investig Allergol Clin Immunol. 2004;14:64-9.

6. Nucera E, Rizzi A, Buonomo A, De Pasquale T, Pecora V, Colagiovanni A, et al. The clinical meaning of positive latex sIgE in patients with food/pollen adverse reactions. Int J Immunopathol Pharmacol. 2012;25:445-53.

7. Bozkurt G, Sackesen C, Civelek E, Kalayci O, Akalan N, Cataltepe O. Latex sensitization and allergy in children with spina bifida in Turkey. Childs Nerv Syst. 2010;26:1735-42, http://dx.doi.org/10.1007/s00381-010-1185-z.

8. Rolland JM, O'Hehir RE. Latex allergy: A model for therapy. Clin Exp Allergy. 2008;38:898-912, http://dx.doi. org/10.1111/j.1365-2222.2008.02984.x.

9. Huda H, Sundaru H, Harsal A, Karyadi TH, Prasetyo SB. Latex allergen sensitization due to glove use among hospital staff in Jakarta and related factors. Acta Med Indones. 2005;37:3-11.

10. Palczynski CM, Walusiak JM, Wittczak TA, Ruta U, Gorski P. Follow-up study on latex allergy in health care workers. J Allergy Clin Immunol. 2002;109(1, Suppl 1):S258.

11. Trapé M, Schenck P, Warren A. Latex gloves use and symptoms in health care workers 1 year after implementation of a policy restricting the use of powdered gloves. Am J Infect Control. 2000;28:352-8, http://dx.doi.org/10.1067/ mic.2000.107199.

12. Allmers H, Schmengler J, Skudlik C. Primary prevention of natural rubber latex allergy in the German health care system through education and intervention. J Allergy Clin Immunol. 2002;110(2):318-23, http://dx.doi.org/10.1067/ mai.2002.126461.

13. Kelly KJ, Wang ML, Klancnik M, Petsonk EL. Prevention of $\operatorname{IgE}$ sensitization to latex in health care workers after reduction of antigen exposure. JOEM. 2011;53(8):934-40, http://dx.doi.org/10.1097/JOM.0b013e31822589dc.

14. Danchaivijitr S, Tangtrakool T, Chokloikaew S, Tamlikitkul V. Universal precautions: Costs for protective equipment. Am J Infect Control. 1997;25(1):44-50.

15. Raulf-Heimsoth M, Yeang HY, Lundberg M, Arif SAM, Bruning Th, Rihs HP. Improvement of the in-vitro diagnostic of natural rubber latex allergy and estimation of cross-reactivity by application of recombinant and natural single allergens. BGFA 2005 [cited 2011 Dec 15]. Available from: http://www.ipa.ruhr-uni-bochum.de/image/ poster/106.pdf.

16. Lucus AD, Tomazic-Jezic VJ. Modification of the Lowry method for analysis of soluble latex proteins. Toxicology Meth. 2000;10(3):165-79.

17. Beezhold DH, Kostyal DA, Tomazic-Jezic VJ. Measurement of latex proteins and assessment of latex protein exposure. Methods. 2002;27(1):46-51, http://dx.doi.org/DOI10.1016/ S1046-2023(02)00050-6.

18. Brown RH, Taenkhum K, Buckley TJ, Hamilton RG. Different latex aeroallergen size distributions between powdered surgical and examination gloves: Significance for environmental avoidance. J Allergy Clin Immunol. 2004;114(2): 358-63, http://dx.doi.org/10.1016/j.jaci.2004.04.003.

19. Tang MB, Leow YH, NG V, Koh D, Goh CL. Latex sensitisation in healthcare workers in Singapore. Ann Acad Med Singapore. 2005;34:376-82.

20. Lin CT, Hung DZ, Chen DY, Wu HJ, Lan JL, Chen YH. A hospital-based screening study of latex allergy and latex sensitization among medical workers in Taiwan. J Microbiol Immunol Infect. 2008;41(6):499-506.

21. Wan KS, Lue HC. Latex allergy in health care workers in Taiwan: prevalence clinical features. Int Arch Occup Environ Health. 2007;80:455-7, http://dx.doi.org/10.1007/s00420006-0146-z.

22. Vangveeravong M, Sirikul J, Dagngsuwan T. Latex allergy in dental students: A cross-sectional study. J Med Assoc Thai. 2011;94(Suppl 3):S1-8. 
23. Yim YS, Park CW, Lee CH. A study of the latex allergy in operating room nurses. Korean J Dermatol. 2002;40(11):1359-66.

24. Leung R, Ho A, Chan J, Choy D, Lai CK. Prevalence of latex allergy in hospital staff in Hong Kong. Clin Exp Allergy. 1997;27(2): 167-74, http://dx.doi.org/10.1111/j.1365-2222.1997.tb00689.x.

25. Teeraratkul A, Dangsuwan T, Kerdsomnuk S, Roengrak S, Vichyanond P, Wittitsuwannakul R. Epidemiology of latex allergy among healthcare personnel at Siriraj hospital. Siriraj Hosp Gaz. 1997;49:837-45.

26. Pridgeon C, Wild G, Ashworth F, Egner W, Ward AM. Assessment of latex allergy in a healthcare population: Are the available tests valid? Clin Exp Allergy. 2000;30:1444-9, http://dx.doi.org/10.1046/j.1365-2222.2000.00908.x.

27. Baur X, Chen Z, Allmers H. Can a threshold limit value for natural rubber latex airborne allergens be defined? J Allergy Clin Immunol. 1998;101(1):24-7, http://dx.doi.org/:10.1016/ S0091-6749(98)70188-5.

28. Allmers H, Brehler R, Chen Z, Raulf-Heimsort M, Fels H, Baur X. Reduction of latex aeroallergens and latex-specific IgE antibodies in sensitized workers after removal of powdered natural rubber latex gloves in a hospital. J Allergy Clin Immunol. 1998;102(5):841-6.

This work is available in Open Access model and licensed under a Creative Commons Attribution-NonCommercial 3.0 Poland License - http://creativecommons.org/ licenses/by-nc/3.0/pl/deed.en. 